\title{
Whole protein uptake and metabolism by mouse blastocysts*
}

\author{
L. B. Pemble † and P. L. Kaye \\ Department of Physiology \& Pharmacology, University of Queensland, St Lucia, Queensland 4067, \\ Australia
}

\begin{abstract}
Summary. Preimplantation mouse embryos take up whole ${ }^{125}$ I-labelled BSA from their environment. In blastocysts this uptake was temperature-sensitive and reversibly inhibited by trypan blue: properties consistent with an endocytotic mechanism. The uptake kinetics indicate that a saturable component predominates at low protein concentrations, but a non-saturable component is the major uptake route at higher concentrations. This suggests that BSA is pinocytosed probably bound to the membrane and dissolved in the bulk solvent phase. The rate of uptake, equivalent to about $5 \mathrm{pl} / \mathrm{min} /$ blastocyst was similar to that reported for non-saturable glycine uptake. In blastocysts the protein is degraded to acid-soluble products. At reported genital tract fluid protein concentrations this would represent a significant contribution to the embryonic pool of fixed nitrogen.
\end{abstract}

\section{Introduction}

Early mammalian development may have evolved with dependence on specific environmental conditions provided by the maternal genital tract. There is evidence that the environmental requirements of the embryo change as development progresses and that these, at least for energy substrates and amino-acids, are met by changes in the maternal environment (Kaye, 1986).

The role of protein in the genital tract fluids has not been determined. There is histological evidence that the embryos of mice (Glass, 1963), rats (Schlafke \& Enders, 1973) and rabbits (Hastings \& Enders, 1974) take up exogenous proteins but the mechanism has not been characterized or quantified.

To investigate how important this protein was to the mouse embryo we have attempted to quantitate the uptake process during development and to characterize its uptake in the blastocyst. A preliminary report of these results has been presented (Kaye, Pemble \& Hobbs, 1986).

\section{Materials and Methods}

Radioiodination of bovine serum albumin. Crystallized bovine serum albumin (BSA, Commonwealth Serum Laboratories, Australia) was radioiodinated at room temperature by using a modification of the chloramine-T method (Greenwood, Hunter \& Glover, 1963) and purified by chromatofocusing (Sernia, 1984). To $10 \mu \mathrm{l}$ of a $4 \mathrm{mg} / \mathrm{ml}$ stock solution of BSA in $0.2 \mathrm{M}$-phosphate buffer $\mathrm{pH} 7.4$ was added $10 \mu \mathrm{l} \mathrm{Na}{ }^{125} \mathrm{I}(100 \mathrm{mCi} / \mathrm{ml}, 11-17 \mathrm{mCi} / \mu \mathrm{g} \mathrm{I}$; Amersham, Australia) in 0.2 M-phosphate buffer, $\mathrm{pH} 7 \cdot 4$. The reaction was started by adding $25 \mu \mathrm{l}$ chloramine-T $(2 \mathrm{mg} / \mathrm{ml})$ and allowed to proceed for $30 \mathrm{sec}$ with constant mixing before adding $25 \mu \mathrm{l}$ sodium metabisulphite $(2 \mathrm{mg} / \mathrm{ml})$ to terminate

\footnotetext{
*Reprint requests to Dr P. L. Kaye.

†Present address: Queensland Institute for Medical Research, Herston, Queensland 4006, Australia.
} 


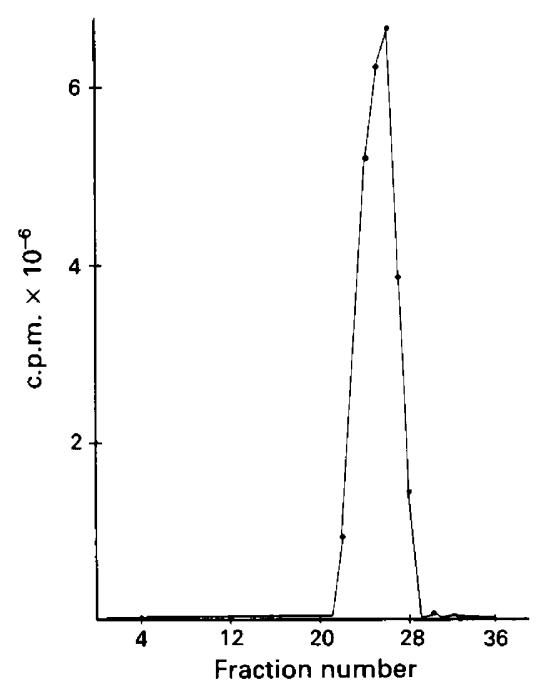

Fig. 1. Purification of ${ }^{125}$ I-labelled BSA on a chromatofocussing column as described in 'Methods'.

iodination. After adding $1 \mathrm{ml} 25 \mathrm{~mm}$-imidazole buffer, $\mathrm{pH} 7 \cdot 4$, the reaction mixture was placed on a chromatofocusing polybuffer exchanger column PBE 94 (Pharmacia Fine Chemicals, Australia; $4 \mathrm{~cm} \times 0.6 \mathrm{~cm}$; bed volume; $1.2 \mathrm{ml}$ ) primed with $10-15 \mathrm{ml} 25$ mM-imidazole- $\mathrm{HCl}$ buffer ( $\mathrm{pH} 7.4)$ and ${ }^{125} \mathrm{I}$-labelled BSA was separated from unreacted $\mathrm{Na}^{125} \mathrm{I}$ by elution with polybuffer 74 (Pharmacia) adjusted to $\mathrm{pH} 4$ with $\mathrm{HCl}$ and diluted 1:8 with $\mathrm{H}_{2} \mathrm{O}$ (Sernia, 1984). Fractions of $0.5 \mathrm{ml}$ were collected and a $10 \mu \mathrm{l}$ sample of each was counted in a Packard Auto-Gamma Scintillation Spectrometer. The 4 fractions containing the peak of radioactivity (Fig. 1) were pooled and dialysed against triple distilled water over 3 days at $4^{\circ} \mathrm{C}$ ( 4 changes each of 2 litres). After dialysis the sample volume was measured and the protein content was determined by the fluorescamine method (Udenfriend et al., 1972). The remainder was divided into $200 \mu \mathrm{l}(\sim 4 \mu \mathrm{g})$ samples, freezedried and stored at $-20^{\circ} \mathrm{C}$. The specific activity of the ${ }^{125} \mathrm{I}$-labelled BSA produced ranged from $6 \cdot 0$ to $13.4 \mathrm{mCi} / \mathrm{mg}$.

Preimplantation mouse embryos. Female Quackenbush mice 6-8 weeks old, randomly bred in our own animal house, were superovulated with 5-10 i.u. PMSG (Folligon, Intervet, Artarmon, N.S.W., Australia) at about 10:00 h and 46-50 h later with 5-10 i.u. hCG (Chorulon, Intervet). Immediately after the hCG injection they were placed with individual males and inspected at 09:00 $\mathrm{h}$ the next day for vaginal plugs. Two-cell embryos, morulae and blastocysts were collected from the mated females (respectively 24,48 and $72 \mathrm{~h}$ later) and washed in Medium M2 (Fulton \& Whittingham, 1978) modified as previously described (Hobbs \& Kaye, 1985).

Uptake studies of ${ }^{125}$ I-labelled BSA. An incubation drop was prepared by addition of $30 \mu l$ BMOC2 medium (Brinster, 1965) modified to contain 0.33 mM-sodium pyruvate, 5.6 mm-glucose and no protein, to one vial of freeze-dried ${ }^{125}$ I-labelled BSA. The test drop was equilibrated under $4 \mathrm{ml}$ silicone fluid (Dow Corning; Australia) for $30 \mathrm{~min}$ in an incubator with an atmosphere of humidified $5 \% \mathrm{CO}_{2} / 95 \%$ air at $37^{\circ} \mathrm{C}$ before the embryos were placed in it. After various times 10-12 embryos were taken from the drop, washed 6 times in $1.5 \mathrm{ml}$ ice-cold Medium M2 and the radioactivity of groups of 3-4 embryos was determined in an LKB automatic gamma counter to yield 3 observations. A sample of the final wash medium was used as background. Statistical analysis of results was by analysis of variance. Values are means \pm s.e.m. 
Preliminary studies in which 2-cell embryos, morulae and blastocysts were incubated in ${ }^{125} \mathrm{I}$-labelled BSA for $3 \mathrm{~h}$ before overnight culture in non-radioactive modified Medium BMOC2 containing unlabelled crystallized BSA at $1 \mathrm{mg} / \mathrm{ml}$ revealed no effects on continued development. Blastocysts appeared normal when inspected under the dissecting microscope after incubation in medium containing ${ }^{125} \mathrm{I}$-labelled BSA and examination of fixed sections of blastocysts showed no apparent damage from this treatment.

\section{Results}

\section{Developmental pattern}

Two-cell embryos, morulae and blastocysts all took up ${ }^{125} \mathrm{I}$-labelled BSA $(18 \mu \mathrm{g} / \mathrm{ml}$, $13 \mathrm{mCi} / \mathrm{mg}$ ) during $3 \mathrm{~h}$ incubation at $37^{\circ} \mathrm{C}$ (Fig. 2). Uptake over this time by blastocysts was 7 times greater than that by morulae and 2-cell embryos $(P<0 \cdot 01)$. The uptake rates of 2 -cell embryos and morulae were low and not significantly different from each other, so further experiments were limited to characterizing the uptake system in blastocysts.

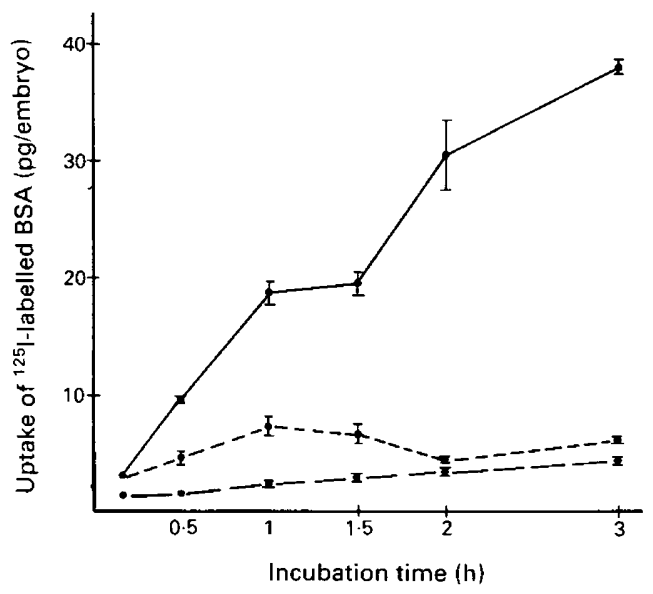

Fig. 2. Uptake of ${ }^{125} \mathrm{I}$-labelled BSA $(18 \mu \mathrm{g} / \mathrm{ml} .13 \mathrm{mCi} / \mathrm{mg})$ by 2-cell mouse embryos $\left({ }_{-}-\infty\right)$, morulae (---), and blastocysts $\left(-17^{\circ} \mathrm{C}\right.$. Each point is the mean \pm s.e.m. of 2 experiments for 2 -cell embryos and 3 for morulae and blastocysts each containing 3 observations at each time and developmental stage.

\section{Effect of incubation temperatures}

Uptake of ${ }^{125} \mathrm{I}$-labelled BSA $(103 \mu \mathrm{g} / \mathrm{ml} ; 8 \mathrm{mCi} / \mathrm{mg})$ by blastocysts over $3 \mathrm{~h}$ was compared at 4 , 22 and $37^{\circ} \mathrm{C}$. The results (Fig. 3) show that uptake at $37^{\circ} \mathrm{C}$ was 5 times greater than at $22^{\circ} \mathrm{C}$ $(P<0.01)$ and 10 times greater than at $4^{\circ} \mathrm{C}(P<0.01)$.

\section{Effect of protein concentration}

Before measurement of uptake by blastocysts over a range of BSA concentrations, the time course of uptake at $18 \mu \mathrm{g} / \mathrm{ml}$ and $10 \mathrm{mg} / \mathrm{ml}$ was determined. The results (Fig. 4) show that for both 


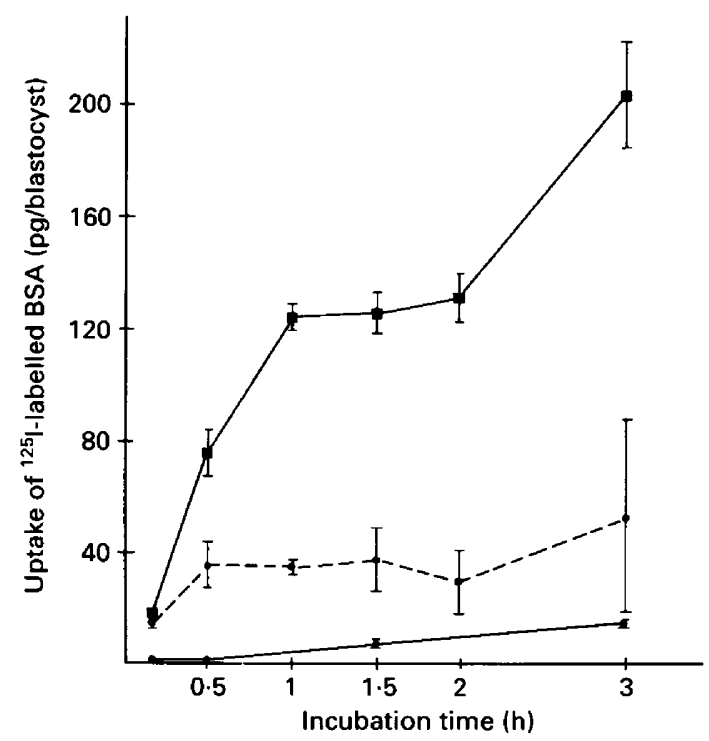

Fig. 3. Temperature dependence of ${ }^{125} \mathrm{I}$-labelled BSA $(103 \mu \mathrm{g} / \mathrm{ml}, 8 \mathrm{Ci} / \mathrm{mg})$ uptake by blasto-

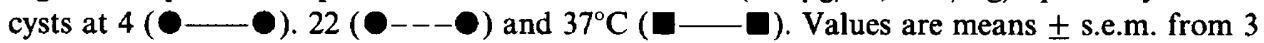
experiments each with 4 observations at each point.

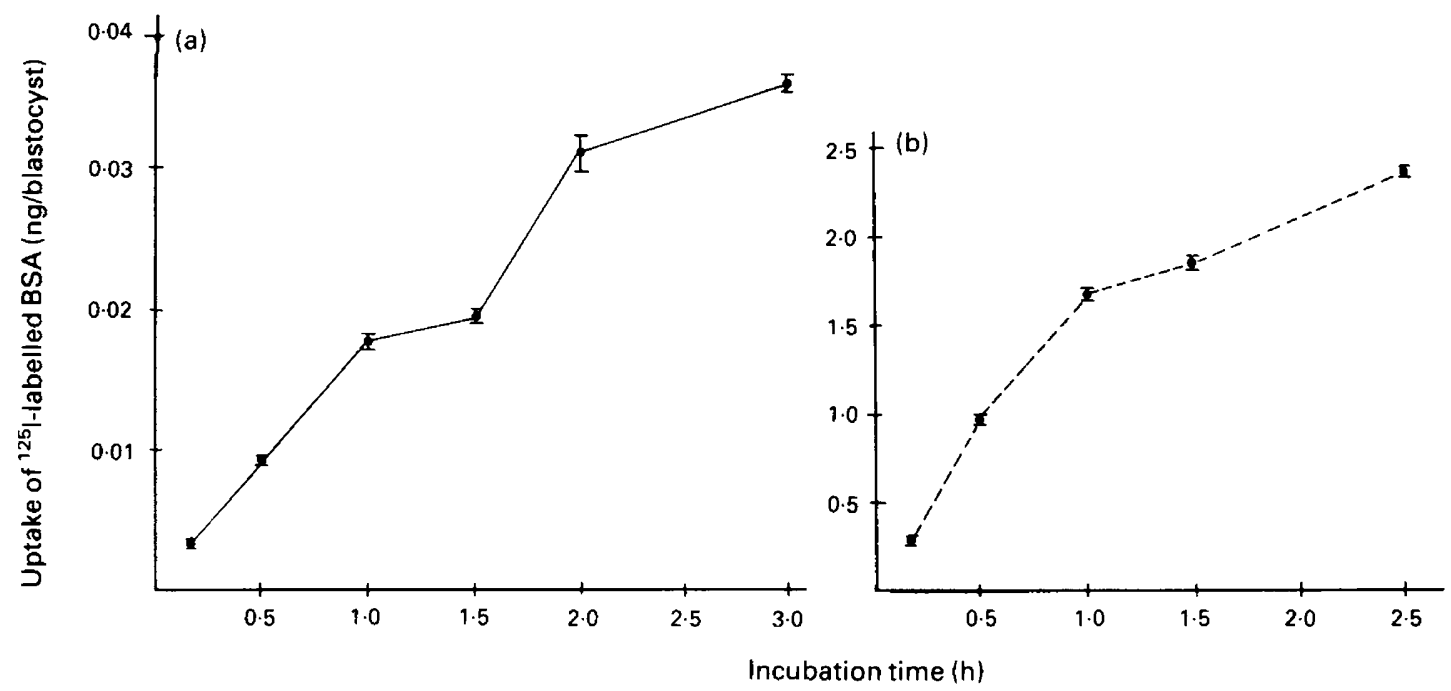

Fig. 4. ${ }^{125} \mathrm{I}$-labelled BSA uptake by blastocysts at $37^{\circ} \mathrm{C}$. Blastocysts were incubated at $37^{\circ} \mathrm{C}$ in Medium BMOC2 containing ${ }^{125}$ I-labelled BSA $(234 \mu \mathrm{Ci} / \mathrm{ml})$ at (a) $18 \mu \mathrm{g} / \mathrm{ml}$, (b) $10 \mathrm{mg} / \mathrm{ml}$ as described in 'Methods'. Each point is the mean \pm s.e.m. of 2 experiments each containing at least 2 observations.

concentrations uptake rate, i.e. ${ }^{125} \mathrm{I}$-labelled BSA taken up per min, was approximately constant during the first hour. At the lower concentration this rate was maintained for $3 \mathrm{~h}$ (Fig. 4a) but at the higher concentration it began to decrease after $1-1.5 \mathrm{~h}$ (Fig. $4 \mathrm{~b}$ ). We therefore chose a period of $30 \mathrm{~min}$ to measure initial uptake rate at a wide range of concentrations (Fig. 5). These results show 


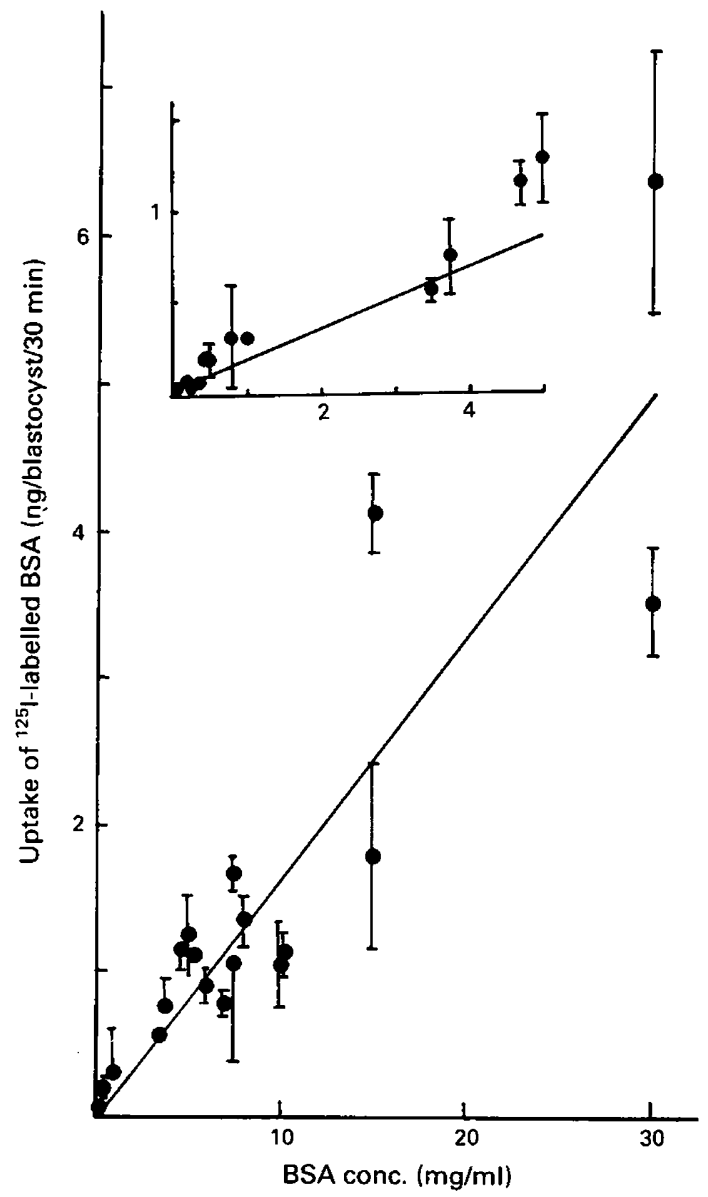

Fig. 5. Effect of protein concentration on ${ }^{125} \mathrm{I}$-labelled BSA uptake by blastocysts at $37^{\circ} \mathrm{C}$. Blastocysts were incubated in Medium BMOC2 containing ${ }^{125} \mathrm{I}$-labelled BSA $(18 \mu \mathrm{g} / \mathrm{ml}-$ $30 \mathrm{mg} / \mathrm{ml}, 234 \mu \mathrm{Ci} / \mathrm{ml}$ ) for $30 \mathrm{~min}$ and uptake measured as described. Results are means \pm s.e.m. from 4 experiments. Line is fitted to means using least squares linear regression.

that the kinetics of uptake appeared to be complex, with indications of a component saturable at low $(<1 \mathrm{mg} / \mathrm{ml})$ BSA concentrations and another component predominating at higher concentrations which was not saturable and was directly related to protein concentration. The line fitted by least squares linear regression to the means was $v=0.033+0.164$ [BSA], $r=0.913, n=29$, where the units of $v$ and [BSA] are $\mathrm{ng} /$ blastocyst $/ 30 \mathrm{~min}$ and $\mathrm{mg} / \mathrm{ml}$ respectively.

\section{Inhibition of uptake by trypan blue}

Trypan blue $(200 \mu \mathrm{g} / \mathrm{ml})$ is a specific, reversible inhibitor of pinosome formation and membrane recycling (Williams, Roberts, Kidston, Beck \& Lloyd, 1976; Field et al., 1977). Preliminary tests showed that the dye did not affect the development of embryos in vitro. We tested its effect on the uptake of ${ }^{125} \mathrm{I}$-labelled BSA by preincubating mouse blastocysts for $30 \mathrm{~min}$ in Medium BMOC2 containing $1 \mathrm{mg} \mathrm{BSA} / \mathrm{ml}$ and $200 \mu \mathrm{g}$ trypan blue $/ \mathrm{ml}$. The uptake of ${ }^{125} \mathrm{I}$-labelled BSA $(194 \mu \mathrm{g} / \mathrm{ml}$; $6 \mathrm{mCi} / \mathrm{mg})$ by blastocysts in medium with trypan blue was only $\sim 30 \mathrm{pg}$, i.e. $10 \%(P<0.01)$ of that by blastocysts in control medium (Fig. 6). 


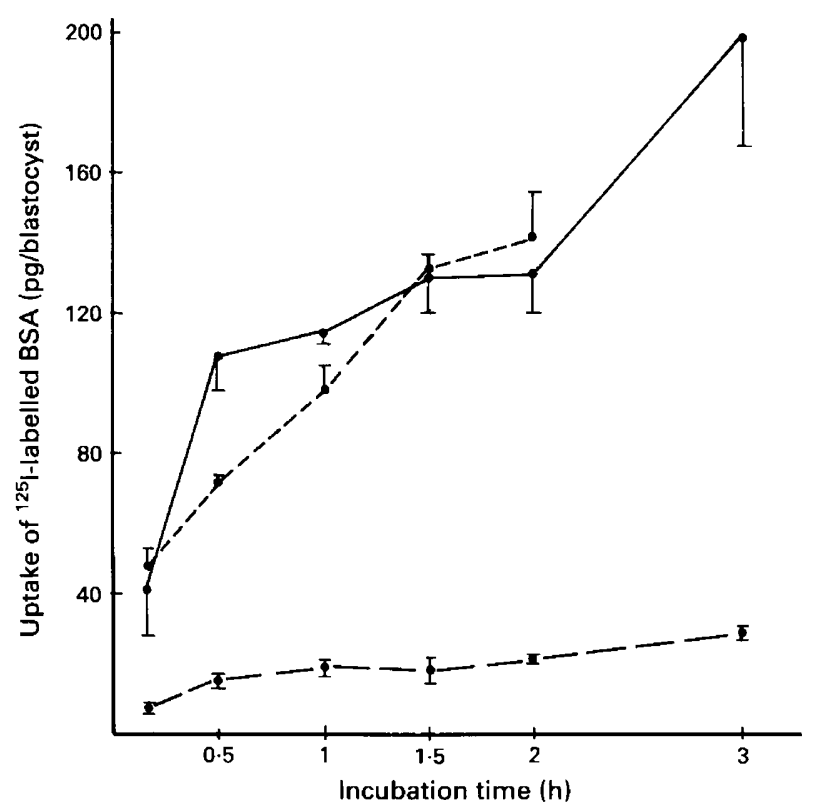

Fig. 6. Effect of trypan blue $(200 \mu \mathrm{g} / \mathrm{ml})$ on uptake of ${ }^{125} \mathrm{I}$-labelled BSA $(195 \mu \mathrm{g} / \mathrm{ml}, 6 \mathrm{mCi} / \mathrm{mg})$. Control incubation ( -3 experiments) + trypan blue (--- 3 experiments). Reversal of inhibition: blastocysts incubated in trypan blue for $2 \mathrm{~h}$, washed and incubated in Medium BMOC2 for $2 \mathrm{~h}$, then incubated in Medium BMOC2 containing ${ }^{125} \mathrm{I}$-labelled BSA (-..-, 2 experiments). For each experiment each point is the mean \pm s.e.m. of 3 observations.

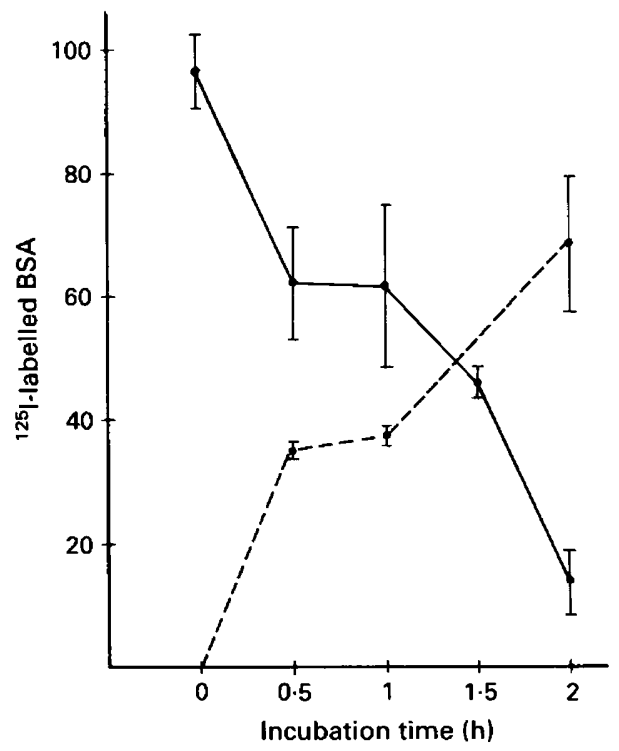

Fig. 7. Catabolism of ${ }^{125}$ I-labelled BSA by blastocysts. Embryos were incubated in Medium BMOC2 containing ${ }^{125} \mathrm{I}$-labelled BSA $(209 \mu \mathrm{g} / \mathrm{ml}, 6.8 \mathrm{mCi} / \mathrm{mg})$ for $2.5 \mathrm{~h}$, washed then transferred at $0 \mathrm{~h}$ to Medium BMOC2 containing BSA $(1 \mathrm{mg} / \mathrm{ml})$. ${ }^{125} \mathrm{I}$-labelled BSA content per blastocyst (-O) and radioactivity released into the medium per blastocyst ( --$\left.)_{-}\right)$were determined. Values are means \pm s.e.m. of 2 experiments each containing 3 observations at each point. 
Reversibility of this effect was tested by preincubating blastocysts for $2 \mathrm{~h}$ in Medium BMOC2 containing $1 \mathrm{mg} \mathrm{BSA} / \mathrm{ml}$ and $200 \mu \mathrm{g}$ trypan blue $/ \mathrm{ml}$. After 6 washes in Medium M2 (at room temperature, $5 \mathrm{~min}$ ), blastocysts were incubated for $2 \mathrm{~h}$ in Medium BMOC2 without trypan blue before ${ }^{125} \mathrm{I}$-labelled BSA uptake was measured. In these blastocysts uptake values were the same as in untreated controls (Fig. 6).

\section{Catabolism of accumulated ${ }^{125}$ I-labelled BSA}

Blastocysts incubated in ${ }^{125} \mathrm{I}$-labelled BSA $(209 \mu \mathrm{g} / \mathrm{ml} ; 6.8 \mathrm{mCi} / \mathrm{mg})$ for $2.5 \mathrm{~h}$ were washed as above. Some were treated with $25 \%$ (w/v) $\mathrm{CCl}_{3} \mathrm{COOH} ; 64 \pm 2.4 \%$ of the radioactivity in the blastocysts was acid-insoluble. Most of this material showed the same mobility as BSA during SDS electrophoresis (results not shown). The remaining blastocysts were placed randomly in droplets of Medium BMOC2 containing unlabelled crystallized BSA $(1 \mathrm{mg} / \mathrm{ml})$. At various times afterwards all the blastocysts from one drop were collected, washed and counted. The results showed a decrease in label in the embryos, corresponding to an increase in label released into the medium (Fig. 7). Samples of the culture media were precipitated with $25 \%(\mathrm{w} / \mathrm{v}) \mathrm{CCl}_{3} \mathrm{COOHG}$ and the radioactivity in the acid-soluble and acid-insoluble fractions assessed. Most $(66 \% \pm 6, n=3)$ of the label released into the medium was acid-soluble.

\section{Discussion}

These experiments were designed to investigate the rate at, and mechanism by, which preimplantation mouse embryos take up whole protein from their environment in vitro. We found that this required high specific radioactivity protein. Of a number of techniques, only radioiodination was successful in achieving the required specific activity. We were concerned that possible contaminants of the ${ }^{125}$ I-labelled BSA introduced by the derivatization reactions (despite the extensive purification of the ${ }^{125}$ I-labelled BSA; Fig. 1), and/or the $\gamma$-radioactivity, might be deleterious to the embryos and thus provide results which did not truly reflect normal embryonic metabolism. However, when 2-cell embryos, morulae or blastocysts were pre-labelled for $2 \mathrm{~h}$ before culture there was no effect on continued development. In addition, light microscopic examination of sections of Aralditeembedded, fixed blastocysts revealed no apparent morphological damage. Moreover, the blastocysts used in the catabolic experiments also appeared normal up to $2 \mathrm{~h}$ after incubation in ${ }^{125}$ I-labelled BSA. We therefore believe there to be no deleterious effects from either the $\gamma$-radiation or the unlikely possibility of a contaminant in the preparation during the period of these experiments.

In common with all uptake experiments these studies required a suitable method of 'washing' embryos to remove ${ }^{125}$ I-labelled BSA not taken up or bound by the embryo. This was achieved by quickly ( $5 \mathrm{~min}$ ) rinsing embryos in small groups through six changes of $2 \mathrm{ml}$ Medium M2 on ice. The experiments on ice showed very little uptake under these conditions and we could find no evidence of losses through this procedure. The catabolic experiments (Fig. 7) show losses from blastocysts of about $6 \%$ over $5 \mathrm{~min}$ at $37^{\circ} \mathrm{C}$. We therefore believe that this procedure reflects the embryonic levels of ${ }^{125} \mathrm{I}$-labelled BSA at the time of removal from the radioactive medium. These observations are similar to those for glycine transport (Hobbs \& Kaye, 1985).

The studies described in Fig. 2 show that ${ }^{125}$ I-labelled BSA was taken up by 2-cell embryos, morulae and blastocysts and that as development proceeds the rate of this process increases about 7 -fold with total uptake over $3 \mathrm{~h}$ by blastocysts being about 5 -fold greater than that by morulae. This confirms earlier histological estimates for increased pinocytosis by blastocysts in comparison with earlier embryonic stages of rats (Schlafke \& Enders, 1973), rabbits (Hastings \& Enders, 1974) and mice (Glass, 1963). This increased activity may reflect the greater metabolic activity of the blastocysts, an increase in cell surface area or result from the differentiation of the outer trophectodermal cells. 
We attempted to characterize the process in blastocysts. Uptake was temperature-dependent (Fig. 3), suggesting a strong metabolic dependence as for endocytosis (Silverstein, Steinman \& Cohn, 1977). However ${ }^{125}$ I-labelled BSA was associated with embryos at $4^{\circ} \mathrm{C}(\approx 20 \mathrm{pg})$, which might reflect binding of ${ }^{125} \mathrm{I}$-labelled BSA to membranes and zona pellucida or trapping in the perivitelline and other extracellular spaces. This conclusion is supported by the electron microscopic studies of rat (Schlafke \& Enders, 1973) and rabbit (Hastings \& Enders, 1974) preimplantation embryos which show exogenous proteins in pinocytotic vesicles and bound to the membrane. Uptake was reversibly inhibited by trypan blue which has been described as a specific reversible inhibitor of pinocytosis (Williams et al., 1976; Field et al., 1977).

These observations are consistent with uptake of BSA by blastocysts via an endocytotic process. The same processes may also occur at earlier stages. Endocytosis may occur by engulfment of membrane adsorbed protein and/or protein dissolved in the bulk fluid. Because of the heterogeneous nature of BSA (Spector, 1975) it is likely that it enters by both routes. This was found in rat yolk sacs (Williams, Kidston, Beck \& Lloyd, 1975). Uptake of BSA bound to membranes should be revealed by a complex dependence of uptake rate on protein concentration. However, it is not possible to determine this from Fig. 5 because of the variability of results due both to variation in blastocyst size and probably endocytotic rate of various ${ }^{125} \mathrm{I}$-labelled BSA preparations (Williams et al., 1975). There is an indication of binding saturated at about $30 \mathrm{pg} / \mathrm{blastocyst}$ from the uptake at $0^{\circ} \mathrm{C}$, in trypan blue and the intercept of the line in Fig. 5.

The endocytotic index calculated from the regression line of Fig. 5 is $5 \mathrm{pl} / \mathrm{min} /$ blastocyst, equivalent to $15 \mu \mathrm{l} / \mathrm{mg}$ protein/h. These figures are close to those reported for the non-saturable component of blastocyst amino-acid uptake (Miller, 1984; Hobbs \& Kaye, 1986) and the endocytotic index for undenatured ${ }^{125}$ I-labelled BSA by rat yolk sacs (Moore, Williams \& Lloyd, 1977) respectively. They represent a considerable fluid flux through the blastocyst.

The catabolic studies show that ${ }^{125}$ I-labelled BSA entered blastocysts as an acid-insoluble macromolecule but was rapidly degraded and the label released as acid-soluble products to the medium. In other cells, this process occurs by lysosomal activity and the only labelled product is ${ }^{125}$ I-labelled tyrosine (Livesey \& Williams, 1981; Kooistra \& Lloyd, 1985). Further studies are required to confirm the identify of the acid-soluble product released by blastocysts. Nonetheless this catabolism of ${ }^{125} \mathrm{I}$-labelled BSA reveals a considerable potential source of amino acids to the blastocyst. Estimates of the protein content ( $\sim 20 \mu \mathrm{g}$ : Aitken, 1977; Pratt, 1977) and volume $(\sim 4 \mu \mathrm{l}$ Edirisinghe \& Wales, 1980;0 $2 \mu \mathrm{l}$ : Hoversland \& Weitlauf, 1981) of flushings of mouse uteri yield an estimated protein concentration of about $10 \mathrm{mg} / \mathrm{ml}$, which is close to that found for rabbit oviduct fluid ( $5 \mathrm{mg} / \mathrm{ml}$ : Shapiro, Jentsch \& Yard, 1971). The uptake rate at this concentration (Fig. 6) would be about $3 \mathrm{ng} / \mathrm{h}$ which would contribute up to $4.5 \mathrm{pmol}$ amino acid from albumin, i.e. about half of the non-taurine amino-acid pool (Schultz, Kaye, McKay \& Johnson, 1981). This ingested protein may not be essential for normal embryonic development, since some embryos developing in vitro to blastocysts in the absence of protein do develop normally after transfer to recipients, albeit at low rates of success (Caro \& Trounson, 1984), but it probably is a usual process during early mammalian development as protein transfer has been observed in vivo (Glass, 1963). The potential nutritive value of material taken up by this endocytosis should not be ignored.

Fleming \& Pickering (1985) have described the presence of horseradish peroxidase-labelled endosomes in mouse embryos of all preimplantation stages. These studies revealed the appearance of secondary lysosomes at the 16-cell stage and increases in the number of endosomes in response to high BSA levels in the medium. These authors also suggest that exogenous proteins may function to a significant extent as a substrate for the recorded upsurge in synthetic activity in the late morula.

We thank Dr C. Sernia for instruction in protein iodination and purification, Dr L. Martin for critical review of the manuscript and Marrianne Hamlet, Fay McElligott and Margaret Muncaster for preparing it. This work was supported by grants to P.L.K. from NHMRC Australia and University of Queensland Special Projects Grants. 


\section{References}

Aitken, R.J. (1977) Changes in the protein content of mouse uterine flushings during normal pregnancy and delayed implantation, and after ovariectomy and oestradiol administration. J. Reprod. Fert. 50, 29-36.

Brinster, R.L. (1965) Studies on the development of mouse embryos in vitro. IV Interaction of energy sources. J. Reprod. Fert. 10, 227-240.

Caro, C.M. \& Trounson, A. (1984) The effect of protein on preimplantation mouse embryo development in vitro. J. in Vitro Fert. Embr. Transf. 1, 183-187.

Edirisinghe, W.R. \& Wales, R.G. (1980) Determinations of the volume and electrolyte content of the uterine fluid of mice during pseudopregnancy. Proc. Aust. Soc. Reprod. Biol. 12, 70, Abstr.

Field, F., Roberts, G., Hallowes, R., Palmer, A., Williams, K. \& Lloyd, J. (1977) Trypan blue: identification and teratogenic and oncogenic activities of its coloured constituents. Chem. Biol. Interactions 16, 69-88.

Fleming, T.P. \& Pickering, S.J. (1985) Maturation and polarization of the endocytotic system in outside blastomeres during mouse preimplantation development. J. Embryol. exp. Morph. 89, 175-208.

Fulton, B. \& Whittingham, D. (1978) Activation of mammalian oocytes by intracellular injection of calcium. Nature, Lond. 273, 149-151.

Glass, L. E. (1963) Transfer of native and foreign serum antigens to oviducal mouse eggs. Am. Zool. 3, 135-156.

Greenwood, F., Hunter, W. \& Glover, J. (1963) The preparation of ${ }^{131}$ I-labelled human growth hormone of high specific activity. Biochem. J. 89, 114-123.

Hastings, R. \& Enders, A. (1974) Uptake of exogenous protein by the preimplantation rabbit. Anat. Rec. 179, 311-330.

Hobbs, J. G. \& Kaye, P. L. (1985) Glycine transport in mouse eggs and preimplantation embryos. $J$. Reprod. Fert. 74, 77-86.

Hobbs. J.G. \& Kaye, P. L. 1986 Glycine and $\mathrm{Na}^{+}$transport in preimplantation mouse embryos. $J$. Reprod. Fert. 77, 61-66.

Hoversland, R.C. \& Weitlauf, H.M. (1981) The volume of uterine fluid in "implanting" and "delayed implanting" mice. J. Reprod. Fert. 62, 105-109.

Kaye, P.L. (1986) Metabolic aspects of the physiology of the preimplantation embryo. In Experimental Approaches to Mammalian Embryonic Development (in press). Eds J. Rossant \& R. Pedersen. Cambridge University Press, New York.

Kaye, P.L., Pemble, L.B. \& Hobbs, J.G. (1986) Protein metabolism in preimplantation mouse embryos. In New Discoveries and Technologies in Developmental Biology (in press). Ed. H.V. Slavkin, Allan R. Liss, Inc., New York.
Kooistra, T. \& Lloyd, J.B. (1985) Degradation of insulin by human fibroblasts: effects of inhibitors of pinocytosis and lysosomal activity. Int. J. Biochem. 17: $805-811$.

Livesey, G. \& Williams, K.E. (1981) Rates of pinocytic capture of simple proteins by rat yolk sacs incubated in vitro. Biochem. J. 198, 581-586.

Miller, J.G.O. (1984) Amino-acid transport in preimplantation mammalian embryos. Ph.D. thesis, University of Calgary, Alberta, Canada.

Moore, A.T., Williams, K.E. \& Lloyd, J.B. (1977) The effect of chemical treatments of albumin and orosomucoid on rate of clearance from the rat bloodstream and rate of pinocytic capture by rat yolk sac cultured in vitro. Biochem. J. 164, 607-616.

Pratt, H.M. (1977) Uterine proteins and the activation of embryos from mice during delayed implantation. $J$. Reprod. Fert. 50, $1-8$.

Schlafke, S. \& Enders, A. (1973) Protein uptake by rat preimplantation stages. Anat. Rec. 175, 539-560.

Schultz, G., Kaye, P., McKay, D. \& Johnson, M. (1981) Endogenous amino acid pool sizes in mouse eggs and preimplantation embryos. J. Reprod. Fert. 61, 387-393.

Sernia, C. (1984) Separation of radioiodinated angiotensins by chromatofocusing in minicolumns. Analyt. Biochem. 138, 303-308.

Shapiro, S., Jentsch, J. \& Yard, A. (1971) Protein composition of rabbit oviducal fluid. J. Reprod. Fert. 24, 403-408.

Silverstein, S., Steinman, R. \& Cohn, Z. (1977) Endocytosis. Ann. Rev. Biochem. 46, 669-722.

Spector, A.A. (1975) Fatty acid binding to plasma albumin. J. Lipid Res. 16, 165-169.

Udenfriend, S., Stein, S., Böhlen, P., Dairman, W., Leimgruber, W. \& Weigele, M. (1972) Fluorescamine: A reagent for assay of amino acids, peptides, proteins and primary amines in the picomole range. Science, N.Y. 173, 871-872.

Williams, K.E., Kidston, E.M., Beck, F. \& Lloyd, J.B. (1975) Quantitative studies of pinocytosis II kinetics of protein uptake and digestion by rat yolk saccultured in vitro. J. Cell Biol. 64, 123-124.

Williams, K., Roberts, G., Kidston, E., Beck, F. \& Lloyd, J. (1976) Inhibition of pinocytosis in rat yolk sac by trypan blue. Teratology 14, 343-354. 